DOI: https://doi.org/10.32838/2523-4803/69-6-14

УДК 338.45:621:005.336.1

\title{
Швець Ю.О.
}

кандидат економічних наук, доцент кафедри фінансів,

банківської справи та страхування,

Запорізький національний університет

\section{Shvets Yuliia}

Zaporizhzhia National University

\section{ТЕОРЕТИКО-ПРИКЛАДНІ ЗАСАДИ ОЦІНКИ ЕФЕКТИВНОСТІ ОПЕРАЦІЙНОЇ ДІЯЛЬНОСТІ ПІДПРИСМСТВ МАШИНОБУДУВАННЯ ТА СПОСОБИ ЇЇ ПОКРАЩЕННЯ}

\begin{abstract}
Встановлено, щзо питання забезпечення ефективності господарської діяльності єосновним завданням для більшості підприємств машинобудування. Тому на підприємствах є потреба у покращценні управління операційною діяльністю, щзо сприятиме зростанню результатів діяльності, формуванню конкурентних переваг, зростанню прибутку. Обгрунтовано, щзо для підприємств машинобудування доцільною є оцінка ефективності операційної діяльності для визначення перспектив розвитку. Досліджено показники операційної діяльності та визначено ї̈ рівень на підприємстві ПрАТ «Бердянські жниварки». Встановлено, щуо відбулося незначне покращення ефективності операційної діяльності підприємства, та враховано інтереси менеджерів, працівників, кредиторів, частково інвесторів. Визначено проблеми, які впливають на ефективність операційної діяльності підприємства. Запропоновано шляхи підвищення ефективності операційної діяльності підприємств машинобудування. Успіх операційної діяльності підприсмства сприятиме зростанню конкурентоспроможності, фінансових показників діяльності.
\end{abstract}

Ключові слова: аналіз, операційна діяльність, ефективність операційної діяльності, фінансові показники, результативність, доходи.

Постановка проблеми. За умов змінності ринкового середовища розвиток підприємств машинобудування відбувається за складних умов, що позначається на ефективності їхнього функціонування, показниках діяльності, рівні розвитку та конкурентоспроможності. Одним зі шляхів стабілізації роботи підприємств є покращення операційної діяльності та ії результатів. Від рівня ефективності операційної діяльності залежить організація виробництва, збут продукції, просування товарів, якість продукції, ефективність роботи персоналу. Тому на підприємствах машинобудування є потреба в оцінці ефективності операційної діяльності, аналізі показників, що дозволить не лише проаналізувати результативність, але й визначити проблеми, шляхи, способи їх подолання, перспективи розвитку підприємства.
Аналіз останніх досліджень і публікацій. Дослідження показників, методів аналізу ефективності операційної діяльності підприємств, особливості управління діяльністю відображено у працях таких учених, як: Н.М. Архіпов [1]; О.М. Бондарчук, Г.В. Темченко, О.С. Максимова [2, с. 90-100]; I. Єрфорт, Ю. Єрфорт [3, с. 215-218]; С. Лобов, В. Нусінов [4, с. 12-16]; М.Д. Никифорчин [5, с. 89-92]; В.П. Ніколаєва [6]; А.В. Осокіна, Ю.М. Чичкан-Хліповка [7, с. 47-54]; О. Рудницька [9, с. 129-134]. Проте недостатньо уваги приділяється питанням оцінки ефективності операційної діяльності підприємств машинобудування, визначенню причин погіршення цього виду діяльності, перспектив розвитку та подолання труднощів. Низка аспектів означеної проблеми 
залишаються недостатньо вивченими та потребують дослідження.

Формулювання цілей статті. Метою статті $\epsilon$ дослідження показників операційної діяльності, аналіз ефективності операційної діяльності підприємств машинобудування в сучасних умовах, з'ясування проблем в управлінні, визначення способів, напрямів, шляхів їх розв'язання та покращення операційної діяльності.

Виклад основного матеріалу дослідження. За умов сучасного розвитку питання ефективності операційної діяльності підприємства є безумовно важливим. Необхідним також є вдосконалення процесу діяльності підприємств, постійно зростає актуальність питання формування конкурентних переваг підприємства, створення конкурентоспроможного продукту, який буде користуватися попитом на ринку збуту та приноситиме позитивний дохід. У процесі діяльності підприємства машинобудування стикаються з багатьма проблемами, які впливають на функціонування як окремих структурних підрозділів підприємства, так і на діяльність підприємства як економічної одиниці загалом. Вагоме значення для підприємств має стан операційної діяльності, адже саме від показників цього сегменту діяльності залежить матеріальний, економічний стан, показники господарської діяльності, успішність виробництва та рівень конкурентоспроможності.

Саме ефективна операційна діяльність дозволить підприємствам машинобудування нарощувати виробничі потужності, отримувати дохід, успішно функціонувати. Від рівня організованості та досконалості операційної діяльності залежить економічне становище підприємства. Тому в умовах глобалізації, змінності впливу чинників ринкового середовища та підвищення стандартів конкурентоспроможності перед підприємствами машинобудування стоїть завдання щодо підвищення ефективності операційної діяльності.

У різних секторах економіки проводиться оцінка ефективності операційної діяльності для визначення результатів діяльності та формування подальших напрямів розвитку. Ефективність операційної діяльності означає прибутковість, раціональне викорис- тання ресурсів, доступних для виробництва, пропорційне співвідношення потреб та можливостей.

Підприємства машинобудування повинні прагнути досягнення більш високого рівня рентабельності, щоби бути більш успішним на ринку. Високі показники діяльності, успішність функціонування підприємства $є$ підставою для налагодження партнерських відносин, укладення нових контрактів, свідчить про інвестиційну привабливість та інноваційний розвиток, кредитоспроможність.

У процесі функціонування на підприємстві доцільно здійснювати аналіз та контроль результатів діяльності як загалом, так і за окремими структурними складниками, аналізувати ефективність роботи підрозділів. Найкращим способом щодо виявлення переваг та недоліків в операційній діяльності є аналіз кожного функціонуючого сегменту окремо, а потім, систематизуючи отримані дані, можна дійти єдиного загального висновку та рішень, які будуть оптимальними для покращення ефективності діяльності підприємства.

Для визначення тенденцій розвитку підприємств машинобудування, оцінки їхнього стану, успішності функціонування доцільним є проведення аналізу операційної діяльності. Аналізування показників операційної діяльності дозволить визначити тенденції розвитку підприємств, ефективність діяльності, причини погіршення чи зростання, проблеми розвитку. Нами було досліджено основні показники операційної діяльності підприємства машинобудування, за аналізом яких можна говорити про результати виробничої, торговельної діяльності, дієвість організації процесу управління кадрами.

У табл. 1 наведені показники операційної діяльності на підприємстві ПрАТ «Бердянські жниварки», які дозволяють стверджувати, що у 2014-2018 рр. склалася неоднозначна ситуація. Зокрема, у 2017 р. маємо покращення показників, зростання виручки від реалізації, суми прибутку, операційного доходу, операційних витрат проти 2016 р. Одночасно у 2018 р. склалася протилежна ситуація та проти 2017 р. відбулися такі зміни: чистий дохід від реалізації продукції (товарів, робіт, послуг) скоротився на 7,73\% (36039 тис. грн.); чистий фінансовий результат (прибуток) зменшився

Таблиця 1

Основні показники операційної діяльності підприємства ПрАТ «Бердянські жниварки» у $2014-2018$ рр.

\begin{tabular}{|c|c|c|c|c|c|}
\hline Показники & 2014 & 2015 & 2016 & 2017 & 2018 \\
\hline Чистий фінансовий результат (прибуток), тис. грн. & 25304 & 30593 & 25835 & 29338 & 25018 \\
\hline Собівартість реалізованої продукції (товарів, робіт, послуг), тис. грн. & 50696 & 104188 & 294094 & 377849 & 313838 \\
\hline Операційний дохід, тис. грн. & 102283 & 189750 & 618944 & 633463 & 575251 \\
\hline Операційні витрати, тис. грн. & 72729 & 156004 & 578766 & 589243 & 521419 \\
\hline Рівень собівартості, \% до чистого доходу & 58,48 & 63,77 & 72,41 & 81,03 & 72,94 \\
\hline Період обороту запасів, днів & 228,86 & 210,81 & 132,33 & 169,08 & 243,94 \\
\hline Період обороту дебіторської заборгованості, днів & 41,23 & 49,62 & 23,51 & 35,46 & 49,92 \\
\hline Тривалість операційного циклу, днів & 270,10 & 260,43 & 155,84 & 204,54 & 293,86 \\
\hline Продуктивність праці, тис. грн./осіб & 22,67 & 12,09 & 50,86 & 11,76 & 14,57 \\
\hline Фондовіддача, грн. & 2,65 & 4,44 & 11,10 & 12,87 & 9,56 \\
\hline Рентабельність операційної діяльності, \% & 1,41 & 1,22 & 1,07 & 1,08 & 1,10 \\
\hline
\end{tabular}

Примітка: складено автором за [8] 
на 14,72\% (4320 тис. грн.); собівартість реалізованої продукції (товарів, робіт, послуг) знизилася на 16,94\% (64011 тис. грн.); сума операційного доходу скоротилася на 9,19\% (58212 тис. грн.); сума операційних витрат зменшилася на 11,51\% (67824 тис. грн.); рівень собівартості скоротився на $8 \%$.

Щодо розрахованих показників, то у 2018 р. маємо таку динаміку: період обороту запасів підвищився на 74,86 днів проти 2017 р., що свідчить про зниження ефективності управління запасами, доцільним є підвищити обсяги виробництва, збуту продукції; період обороту дебіторської заборгованості у порівнянні з 2017 р. виріс на 14,46 днів, розмір дебіторської заборгованості зростає пропорційно обсягу виробництва продукції; тривалість операційного циклу виросла на 89,32 днів проти 2017 р., для іï скорочення доцільно покращити управління дебіторською заборгованістю, що позитивно вплине на фінансовий результат; показник продуктивності праці підвищився на 23,89\% проти 2017 р., адже підвищився обсяг виробництва продукції та збільшилася кількість працівників на 46 осіб; показник фондовіддачі скоротився на 25,73\% проти 2017 р., що говорить про певні проблеми в управлінні основними засобами. Слід зауважити, що у 2017-2018 рр. відбулося покращення рівня рентабельності операційної діяльності, що відображає можливості підприємства до підвищення результатів фінансово-господарської діяльності, зацікавленість керівництва у зростанні рівня конкурентоспроможності.

Проаналізувавши показники операційної діяльності ПрАТ «Бердянські жниварки», бачимо, що у 2018 р. на підприємстві є низка проблем та відбулося незначне погіршення аналізованих показників, але незрозумілою є ефективність цього виду діяльності. Тому для оцінки ефективності операційної діяльності підприємства, визначення проблем в управлінні операційною діяльністю слід застосувати методологію оцінювання економічної ефективності, що наведена в роботі С. Лобова, В. Нусінова [1; 4, с. 13-16].

На підставі застосування методології було розраховано величину EBITDA, показники ефективності операційної діяльності підприємства ПрАТ «Бердянські жниварки», що наведено в табл. 2. Під час розрахунку показника EBITDA, на відміну від традиційного підходу, авторами було враховано суму операційного прибутку та амортизацію, що відноситься до оплаченої частини основних фондів [4, с. 13-16].

Відповідно до традиційної методики було розраховано значення EBITDA, яке у 2018 р. проти 2017 р. скоротилося на 9,27\%, а також, скориставшись запропонованою авторами методикою, визначено EBITDA, який у порівнянні з 2017 р. скоротився на 9,25\%. У першому разі значення показника EBITDA є завищеним, у другому - більш точним, тому більш грунтовно відображає економічну ефективність операційної діяльності підприємства. Крім того, під час розрахунку EBITDA доцільним є виключення амортизації, що відноситься до неоплаченої частини основних фондів. Далі розраховано показники ефективності операційної діяльності по ПрАТ «Бердянські жниварки», у 2018 р. склалася така ситуація: коефіцієнт відношення EBITDA до операційних витрат підвищився на 2,55\% проти 2017 р.; у порівнянні з 2017 р. коефіцієнт співвідношення EBITDA до власного капіталу скоротився на 22,34\%; коефіцієнт співвідношення зарплати до EBITDA проти 2017 р. підвищився на 34,26\%; коефіцієнт співвідношення EBITDA до заборгованості перед кредиторами виріс на 23,38\% проти 2017 р. За результатами проаналізованих показників слід відзначити, що за 2018 р. підприємство є привабливим 3 погляду менеджерів, працівників, кредиторів, що пов'язано зі зростанням суми заробітної плати працівників, скороченням суми операційних витрат, зменшенням заборгованості перед кредиторами. Проте підприємство має низький рівень інвестиційної привабливості, ефективність операційної діяльності має незначну тенденцію до покращення.

Проведений аналіз дає змогу відзначити, що під час оцінки ефективності операційної діяльності підприємства враховано інтереси менеджерів, працівників, кредиторів та частково інвесторів і спостерігається динаміка до повільного покращення операційної діяльності. Відповідно до отриманих результатів керівництву слід звернути увагу на покращення ефективності операційної діяльності в наступних періодах шляхом

Таблиця 2

Показники ефективності операційної діяльності підприсмства ПрАТ «Бердянські жниварки» у $2014-2018$ рр.

\begin{tabular}{|l|c|c|c|c|c|}
\hline \multicolumn{1}{|c|}{ Показники } & $\mathbf{2 0 1 4}$ & $\mathbf{2 0 1 5}$ & $\mathbf{2 0 1 6}$ & $\mathbf{2 0 1 7}$ & $\mathbf{2 0 1 8}$ \\
\hline неоплачена частина основних засобів, придбаних у кредит & 35153 & 38397 & 34804 & 37662 & 52366 \\
\hline оплачена частина основних засобів & 29329 & 33000 & 40017 & 53077 & 64494 \\
\hline Операційний прибуток (ЕВIT) & 102283 & 189750 & 618944 & 633463 & 575251 \\
\hline Загальна сума амортизації & 1883 & 3806 & 9119 & 13637 & 11887 \\
\hline EBITDA за загальноприйнятою методикою & 104166 & 193556 & 628063 & 647100 & 587138 \\
\hline Амортизація по оплаченій частині основних засобів & 1600,55 & 3235,1 & 7751,15 & 11591,45 & 10103,95 \\
\hline ЕВITDА за використаною методикою (Лобов С., Нусінов В.) & 103883,6 & 192985,1 & 626695,2 & 645054,5 & 585354,95 \\
\hline ЕВITDA / Операційні витрати & 1,43 & 1,24 & 1,08 & 1,09 & 1,12 \\
\hline ЕВITDА / Власний капітал & 1,85 & 2,22 & 5,26 & 4,34 & 3,37 \\
\hline Зарплата / (ЕВІТDА + Зарплата) & 0,07 & 0,05 & 0,03 & 0,05 & 0,07 \\
\hline EBITDA / Заборгованість перед кредиторами & 3,04 & 4,86 & 7,22 & 3,03 & 3,74 \\
\hline
\end{tabular}

Примітка: складено автором за [8] 
збалансування інтересів працівників, менеджерів, інвесторів, кредиторів та держави.

3 наведених вище даних ми бачимо, які проблеми виникають під час діяльності підприємства та аналізування операційної діяльності дозволяє виявити потенційні загрози, які можуть вплинути на фінансовий стан та завадити успішному функціонуванню.

За результатами аналізу показників операційної діяльності підприємства слід зупинитися на визначенні проблем, які виникають під час операційної діяльності: відсутність налагодженої системи комунікації на підприємстві, нераціональна інвестиційна діяльність, низький рівень інноваційного розвитку, неправильно визначений цільовий ринок споживачів, неефективність використання основних засобів, повільне підвищення кваліфікації працівників, надмірні витрати на збут продукції, відсутність сучасної маркетингової політики, нестача фінансових ресурсів, нераціональне витрачання коштів.

Серед основних способів, які можуть бути використані для виправлення зазначених проблем та задля підвищення операційної діяльності підприємства, слід дотримуватися: спрямування інвестиційних ресурсів у вигідні та сучасні проекти, які є потенційно прибутковими в майбутньому; проведення підготовки та перепідготовки для працівників, що спрямовано на підвищення рівня знань; впровадження іноземного досвіду; застосування на підприємстві більш сучасного обладнання, модернізація та автоматизація виробництва; планування витрат та їх скорочення; визначення ринків збуту; підвищення конкурентоспроможності власного товару, створення більш якісного продукту; врахування потреб споживачів; організація ефективної маркетингової політики та активізація роботи відділу маркетингу; врахування інтересів працівників, менеджерів, інвесторів, кредиторів та держави; використання програмного забезпечення; створення належних умов роботи для працівників.

Підприємства функціонують в конкурентному середовищі, і тому для підвищення ефективності операційної діяльності підприємств машинобудування доцільно здійснювати такі дії: для збільшення ефективності стратегічного сектору - покращити роботу маркетингового відділу, просувати продукцію на внутрішній та зовнішній ринок, аналізувати ситуацію на ринку збуту (ціна, якість, асортимент товарів та послуг), порівнювати показники діяльності з попередніми періодами, коригувати стратегію підприємства відповідно до зміни ситуації на ринку; для покращення бізнес-процесів - залучати інвестиційний капітал в операційну діяльність, коригувати витрати при впровадженні інноваційних технологій, формувати інноваційні напрями розвитку, застосовувати реінжинірингові процеси, інформатизація підрозділів підприємства, налагоджувати логістику, вдосконалювати систему обслуговування підприємства, враховувати інтереси внутрішніх та зовнішніх споживачів; для підвищення операційної діяльності підприємства - застосовувати мотиваційностимулюючі заходи для робітників, навчати праців- ників, застосовувати прогресивні методи управління персоналом, вдосконалювати систему комунікацій на підприємстві, замінити застаріле обладнання, оновлювати основні фонди, впроваджувати ефективні і конкурентоспроможні способи виробництва, іноземний досвід; для мінімізації витрат операційної діяльності використовувати продуктивне, автоматизоване та енергоощадне обладнання, раціонально застосовувати основні фонди, нові, сучасні дослідження та розробки, впроваджувати сучасні технології виробництва, зміна обсягів виробництва, коригувати організацію виробництва і праці, здійснювати контроль над витратами.

Покращення ефективності операційної діяльності підприємств машинобудування потребує значних витрат та коригування діяльності структурних підрозділів, відділів та підприємства в цілому і вимагає комплексного застосування усіх способів.

Поряд зі шляхами покращення операційної діяльності підприємств також доцільно виділити методи іï оцінки, а саме: за стратегічним напрямом проводиться розробка операційної стратегії, стратегічного плану розвитку операційної діяльності шляхом застосування збалансованої системи показників, SWOT-аналізу, PEST-аналіу, кореляційно-регресійного аналізу, стратегічних карт, матриці Бостонської групи, вартіснофункціонального аналізу, сценарного підходу; за поточним напрямом відбувається розробка поточного плану операційної діяльності, реалізація стратегії на підставі факторно-аналітичного методу, XYZ-методу, ABC-методу, CVP-аналізу, нормативного методу, діаграми Парето, методу оцінки ефективності бізнеспроцесів, методу КРI, моделі EOQ; за оперативним напрямом здійснюється розробка та виконання оперативно-календарних планів операційної діяльності шляхом використання методу порівняння, бюджетування, методу PERT, методу GANTT [10].

Таким чином, за результатами аналізу ефективності операційної діяльності підприємства можна сказати, що рівень ефективності цього виду діяльності залежить від ситуації на ринку, впливу чинників внутрішнього та зовнішнього середовища, а також впливає на конкурентоспроможність, успіх виробничо-господарської діяльності. Передумовою прибутковості, уникнення кризового стану, фінансової стабільності $є$ вдала організація виробничого процесу, регулювання всіх напрямів діяльності, врахування змін ринку, застосуванням новацій та вдосконалень на підприємстві. Підприємства машинобудування повинні постійно вдосконалювати процес операційної діяльності, здійснювати моніторинг ринку та аналізувати стан конкуренції для результативного функціонування.

Висновки 3 цього дослідження. Функціонуючи підприємства машинобудування стикаються з багатьма проблемами, які впливають як на роботу структурних підрозділів, так і на діяльність підприємства загалом. Особливо вагому роль для успіху функціонування підприємства має стан операційної діяльності, від показників якої залежить матеріальний, економічний 
стан підприємства, рівень конкурентоспроможності, формування конкурентних переваг. Ефективність операційної діяльності підприємства свідчить про рентабельність діяльності, результативність процесу виробництва продукції, торговельної діяльності.

Проаналізовано показники операційної діяльності, визначено рівень ефективності цієї діяльності на ПрАТ «Бердянські жниварки» та з'ясовано, що слід звернути увагу на покращення виробничої діяльності, розширення ринків збуту, збільшення обсягів виробництва та збуту продукції, раціонально використовувати та розподіляти ресурси, враховувати інтереси працівників, менеджерів, інвесторів, кредиторів та держави. Для підвищення ефективності операційної діяльності підприємства доцільним є посилення контролю, пла- нування результатів роботи та вдосконалення виробництва продукції, маркетингової діяльності, розширення ринків збуту.

У роботі зазначено способи, шляхи, напрями підвищення ефективності операційної діяльності підприємств машинобудування, а саме: визначення ринків збуту, прийняття на роботу кваліфікованих працівників, залучення інвестиційних ресурсів, активізація маркетингової діяльності, заміна застарілого обладнання, модернізація виробництва, використання сучасного програмного забезпечення. Успіх операційної діяльності підприємства $є$ можливим за умови впровадження інновацій, сучасних методів, способів, шляхів покращення операційної діяльності, здійснення управління діяльністю.

\section{Список літератури:}

1. Архіпов Н.М. Управління ефективністю операційної діяльності підприємства роздрібної торгівлі: автореф. дис. ... канд. екон. наук: 08.00.04 / Київський національний торговельно-економічний університет. Київ, 2019.20 с.

2. Бондарчук О.М., Темченко Г.В., Максимова О.С. Оптимізація ефективності діяльності промислового підприємства гірничої галузі. Економічний вісник Національного гірничого університету. 2018. № 1. С. 89-101.

3. Єрфорт І., Єрфорт Ю. Ефективність операційної діяльності підприємств. Економічний аналіз. 2012. Вип. 11(2). С. 215-219.

4. Лобов С., Нусінов В. Оцінювання ефективності операційної діяльності підприємств для різних суб'єктів оцінювання. Збірник наукових пращь Черкаського державного технологічного університету. Серія: Економічні науки. 2014. Вип. 38(1). С. 12-17.

5. Никифорчин М.Д. Суть та основні поняття операційної ефективності в діяльності підприємства. Науковий вісник Херсонського державного університету. Серія: Економічні науки. 2013. Вип. 3. С. 88-92.

6. Ніколаєва В.П. Оцінка ефективності управління формуванням доходів з операційної діяльності підприємства. Ефективна економіка. 2014. № 7. URL: http://www.economy.nayka.com.ua/?op=1\&z=3207 (дата звернення: 01.12.2019).

7. Осокіна А.В., Чичкан-Хліповка Ю.М. Теоретико-прикладні аспекти управління операційною ефективністю підприємства. Чернігівський науковий часопис. Серія 1: Економіка і управління. 2015. № 1(6). С. 46-56.

8. Офіційний сайт ПрАТ «Бердянські жниварки». URL: http://zhatki.pat.ua/ (дата звернення: 01.12.2019).

9. Рудницька О. Аналіз операційної діяльності за основними бізнес-процесами торговельних підприємств. Вісник Тернопільського національного економічного університету. 2016. Вип. 4. С. 128-135.

10. OperationalEfficiency:ConceptualFramework.URL:https://shodhganga.inflibnet.ac.in/bitstream/10603/134535/7/07 chapter\%201.pdf (дата звернення: 01.12.2019).

\section{References:}

1. Arkhipov N.M. (2019). Upravlinnia efektyvnistiu operatsiinoi diialnosti pidpryiemstva rozdribnoi torhivli [Management of the operational efficiency of the retail business] ( $\mathrm{PhD}$ Thesis), Kyiv: Kyiv National University of Trade and Economics.

2. Bondarchuk O.M., Temchenko H.V., Maksymova O.S. (2018). Optymizatsiia efektyvnosti diialnosti promyslovoho pidpryiemstva hirnychoi haluzi [Efficiency optimization of industrial mining companies activity]. Economic Bulletin of the National Mining University, no. 1, pp. 89-101.

3. Erfort I., Erfort Y. (2012). Efektyvnistj operacijnoji dijaljnosti pidpryjemstv [Efficiency of operating activities of enterprises]. Economic analysis, vol. 11(2), pp. 215-219.

4. Lobov S., Nusinov V. (2014). Otsiniuvannia efektyvnosti operatsiinoi diialnosti pidpryiemstv dlia riznykh sub'iektiv otsiniuvannia [Assessment of the efficiency of enterprises trading activities for various subjects of assessment]. Proceedings of Scientific Works of Cherkasy State Technological University Series Economic Sciences, vol. 38(1), pp. $12-17$.

5. Nikiforchin M.D. (2013). Sut ta osnovni poniattia operatsiinoi efektyvnocti v diialnosti pidpryiemstva [Nature and basic concepts operational efficiency in the enterprise]. Scientific Bulletin of Kherson State University. Series: Economic Sciences, vol. 3, pp. 88-92.

6. Nikolaeva V.P. (2014). [Evaluating the effectiveness of management of income generation from operating activities of the enterprise]. Journal «Efektyvna ekonomika», no. 7. Available at: http://www.economy.nayka.com.ua/?op=1\&z=3207 (accessed 01 December 2019).

7. Osokina A.V., Chychkan-Khlipovka Y.N. (2015). Teoretyko-prykladni aspekty upravlinnia operatsiinoiu efektyvnistiu pidpryiemstva [Theoretical and applied aspects of enterprise's operational efficiency management]. Chernihiv scientific journal. Series 1: Economics and Management, no. 1(6), pp. 46-56.

8. Official site of JSC Berdyansk harvesters. Available at: http://zhatki.pat.ua/ (accessed 01 December 2019). 
9. Rudnitskaya O. (2016). Analiz operatsiinoi diialnosti za osnovnymy biznes-protsesamy torhovelnykh pidpryiemstv [Analysis of operating activities by major business processes of trading enterprises]. Bulletin of the Ternopil National Economic University, vol. 4, pp. 128-135.

10. Operational Efficiency: Conceptual Framework. Available at: https://shodhganga.inflibnet.ac.in/bitstream/10603/ 134535/7/07_chapter\%201.pdf (accessed 01 December 2019).

\section{ТЕОРЕТИКО-ПРИКЛАДНЫЕ ОСНОВЫ ОЦЕНКИ ЭФФЕКТИВНОСТИ ОПЕРАЦИОННОЙ ДЕЯТЕЛЬНОСТИ ПРЕДПРИЯТИЙ МАШИНОСТРОЕНИЯ И СПОСОБЫ ЕЕ УЛУЧШЕНИЯ}

Установлено, что вопрос обеспечения эффективности хозяйственной деятельности является основной задачей для большинства предприятий машиностроения. Поэтому на предприятиях существует потребность в улучшении управления операционной деятельностью, что будет способствовать росту результатов деятельности, формированию конкурентных преимуществ, росту прибыли. Обосновано, что для предприятий машиностроения иелесообразна оценка эффективности операционной деятельности для определения перспектив развития. Исследованы показатели операционной деятельности и определен ее уровень по предприятию ЧАО «Бердянские жатки». Установлено, что произошло незначительное улучшение эффективности операционной деятельности предприятия, и учтены интересы менеджеров, работников, кредиторов, частично инвесторов. Определены проблемы, которые влияют на эффективность операционной деятельности предприятия. Предложены пути повышения эффективности операционной деятельности предприятий машиностроения. Успех операционной деятельности предприятия способствует росту конкурентоспособности, финансовых показателей деятельности.

Ключевые слова: анализ, операџионная деятельность, эффективность операџионной деятельности, финансовые показатели, результативность, доходыл.

\section{THEORETICAL AND APPLIED PRINCIPLES OF ESTIMATION OF OPERATIONAL EFFICIENCY OF MACHINE-BUILDING ENTERPRISES AND WAYS OF ITS IMPROVEMENT}

It is established that the issue of ensuring the efficiency of economic activity is the main task for most mechanical engineering enterprises, which is exacerbated in the conditions of aggravation of competition, instability of economic conditions. Therefore, there is a need for enterprises to improve the management of operations, which will contribute to the growth of business results, the formation of competitive advantages, the growth of profits. It is substantiated that for the enterprises of mechanical engineering it is expedient to evaluate the efficiency of operational activity for determining the prospects of development. The indicators of operating activity are investigated and its level is determined by the enterprise of PJSC «Berdyansk harvesters». It was found that there was a slight improvement in the efficiency of the operating activities of the enterprise and took into account the interests of managers, employees, creditors, and partly investors. However, the management of the company should pay attention to improving the efficiency of operating activities in the coming periods, to increase production and sales of products, to improve personnel management, production activities. The problems that influence the efficiency of the enterprise's operational activity are identified: lack of a well-established communication system at the enterprise, irrational investment activity, low level of innovative development, incorrectly defined target market of consumers, inefficient use of fixed assets, slow training of employees, excessive production costs, modern marketing policy, lack of financial resources, irrational spending. The ways of increase of efficiency of operational activity of the enterprises of machine-building are offered: improvement of activity of business processes, increase of efficiency of strategic sector, information support, training of personnel, modernization and automation of production, minimization of expenses of operational activity, rationalization of use of resources. In order to increase the efficiency of machine-building enterprises, it is necessary to carry out complex work not over a particular sector of production management, but over the entire production system. The success of the operating activities of the enterprise will contribute to the increase of competitiveness, financial performance.

Key words: analysis, operational activity, efficiency of operating activity, financial indicators, efficiency, income. 